\title{
The effects of some dietary changes upon the concentrations of serum lipids in rats
}

\author{
By D. McGREGOR* \\ Flour-Milling and Baking Research Association, Old London Road, St Albans, Herts
}

(Received 8 April 1970-Accepted I September 1970)

\begin{abstract}
I. The responses of serum lipids of weanling and adult male rats to different diets have been examined. Total cholesterol, phospholipids and triglycerides were measured. The proteins used in the diets were casein and wheat gluten, the carbohydrates were starch and sucrose, and the main lipid source was groundnut oil supplemented with either gluten oil or maize oil.

2. In general, the type of carbohydrate did not influence the experimental results, whereas the type of protein had a marked effect. Compared with casein, gluten caused an increase in concentration of serum triglycerides, phospholipids and cholesterol in weanling rats, but there was no change in adult animals. Much of this 'gluten effect' in weanlings was not observed when the diet was supplemented with $0.7 \%$ L-lysine hydrochloride.

3. When $\mathrm{x} \%$ cholesterol was added to the gluten diets, the serum cholesterol concentrations were only slightly and variably affected in weanlings. Serum triglycerides and phospholipids were not altered in adult rats by the dietary cholesterol, whereas there were reductions in these lipid components in the weanlings, whether the protein was supplemented with L-lysine hydrochloride or not.

4. Gluten oil was not shown to be responsible for any major portion of the differences observed between gluten and casein in their effects upon the lipids of rat serum.
\end{abstract}

Many experiments in different laboratories have shown that the concentrations of cholesterol, phospholipids and triglycerides in rat serum change in response to dietary manipulations. Particular interest has been shown in the separate actions of carbohydrates, lipids and proteins, but somewhat less interest has been displayed in the interactions of these components. The experiments described were prompted by the unexpected results of earlier (unpublished) trials which indicated that in male, but not in female, rats the serum lipid concentrations were higher if the animals were fed on high-protein bread supplemented with lysine than if they were fed on a diet containing $21 \%$ casein and $67 \%$ starch for 15 weeks. In another, earlier, experiment, male weanling rats were fed for $\mathrm{I} 3$ weeks on diets containing either $70 \%$ starch or $70 \%$ sucrose; the protein in each diet was $10 \%$ casein plus 10\% gluten. There were no differences between these groups, suggesting that the serum lipid concentrations of rats are more greatly influenced by the nature of the protein in the diets than by the type of carbohydrate.

The objects of the experiments reported here were to compare the effects of combining each of the carbohydrates, starch and sucrose, with the proteins, wheat gluten and casein, both in the presence and in the absence of cholesterol.

Several previous studies have concentrated upon variations in serum cholesterol values, but at least equal importance is now given to conditions which alter serum triglyceride concentration.

* Present address: Nuffield Unit for Laboratory Animal Pathology, 19 Chalmers Street, Edinburgh 3. 


\section{EXPERIMENTAL}

Animals

The animals used were litter-mate sets of male rats of Ash/Wistar, Carworth Europe or St Albans hooded strains. Adults were used in Expt $\mathrm{I}$ and weanlings in all subsequent experiments.

\section{Dietary materials}

Casein was obtained from British Drug Houses, Poole, Dorset and contained $92.3 \%$ protein, $0.14 \%$ lipid, $\mathrm{I} \cdot 76 \%$ ash and $\mathrm{I} \cdot 8 \%$ water; the untreated gluten from Australian wheat contained $69.8 \%$ protein, $4.8 \%$ lipid, $0.9 \%$ ash, $8.2 \%$ water and about $16 \%$ starch. Since there were reasons for considering that the lipid in gluten would affect the response of the rats to gluten-containing diets, a low-fat gluten was prepared. The commercial preparation was extracted successively with light petroleum (b.p. $60-80^{\circ}$ ), hot n-butanol, methanol and light petroleum (b.p. $<40^{\circ}$ ). The solvent was evaporated from the gluten in a vacuum oven at $50^{\circ}$; the oil was recovered from the solutions in a rotary evaporator at $40^{\circ}$. Defatted gluten contained $70.1 \%$ protein, $0.88 \%$ lipid, $0.4 \%$ ash, $7.1 \%$ water and about $21 \%$ starch (by difference). The oil, which was very viscous and brown, was divided into two parts and one was added back to some of the defatted gluten without further treatment; the other was exhaustively extracted with acetone to give a phospholipid-rich oil and a phospholipid-depleted oil. These oils were also added back, separately, to some defatted gluten and used in Expt 4.

Other materials used in the preparation of the diets were starch, sucrose, mineral salts (Jones \& Foster, 1942), cholesterol, L-methionine, L-lysine and L-glutamine, all of which were obtained from British Drug Houses, Poole, Dorset, Vitamin Fortification Mixture (Nutritional Biochemicals Corp., Cleveland, Ohio), maize oil (Mazola; Brown and Polson Ltd, Esher, Surrey) and groundnut oil (Spillers Ltd, Cambridge).

\section{Diets}

The diets were mixed to give the compositions shown in Table I. Owing to the large differences in the compositions of the three proteins used (casein, gluten and defatted gluten), it proved impossible to make up diets based on different proteins to contain equal quantities of protein nitrogen, lipid and carbohydrate. In order to reduce effects due to nitrogen deficiency in the gluten-containing diets, high proportions (c. $20 \%$ ) of protein were used.

Essential fatty acids are normally present in appreciable quantities in gluten, so diets which contained casein were always supplemented with maize oil in order to minimize this source of difference in the diets.

Lysine was added to some gluten diets to make up for the relative deficiency of this essential amino acid in the protein. Gluten is rich in L-glutamine, so this amino acid was added to one of the casein diets. Methionine is a methyl group donor in 'onecarbon' metabolism and, since the level of this amino acid may be critical in casein, thereby affecting cholesterol metabolism, casein was fortified with methionine in one of the diets. 


\section{Experimental procedure}

The rats were caged singly and provided with food and water ad lib. Reliable food consumption values were available owing to the use of a feeding-pot designed by the late Dr Pace and by Mr Tomlinson at the Flour-Milling and Baking Research Association, St Albans. Body-weight changes were recorded during each experiment.

At the end of the $14-28 \mathrm{~d}$ feeding periods, the animals were fasted for $16-18 \mathrm{~h}$ and then killed by decapitation under light ether anaesthesia. The free-flowing blood was collected in glass centrifuge tubes and allowed to clot at room temperature; serum thus obtained was stored in a deep-freeze cabinet.

Table I. Compositions of the diets used in the various experiments

(Vitamins $(2 \%)$ and salts $(4 \%)$ were present in all diets. Carbohydrate (starch or sucrose) constituted $55.5 \%$ in all diets)

\begin{tabular}{|c|c|c|c|c|c|}
\hline Expt & Diet & Protein & $\begin{array}{l}\text { Carbo- } \\
\text { hydrate }\end{array}$ & Oil & Other additives \\
\hline $1,2,3,5$ & A & $22 \%$ casein & Starch & $\begin{array}{l}\text { I5 } \% \text { groundnut, } \\
\text { I. } 5 \% \text { maize }\end{array}$ & - \\
\hline$I, 2$ & B & $22 \%$ casein & Sucrose & $\begin{array}{l}\text { I } 5 \% \text { groundnut, } \\
\text { I. } 5 \% \text { maize }\end{array}$ & - \\
\hline$, 2,3,5$ & $\mathrm{C}$ & $23.5 \%$ gluten & Starch & $15 \%$ groundnut & 一 \\
\hline $\mathrm{I}, 2$ & $\mathrm{D}$ & $23.5 \%$ gluten & Sucrose & I $5 \%$ groundnut & - \\
\hline$I, 2,5$ & $\mathrm{E}$ & $23.5 \%$ gluten & Starch & $14 \%$ groundnut & I $\%$ cholesterol \\
\hline $\mathrm{I}, 2$ & $\mathbf{F}$ & $23.5 \%$ gluten & Sucrose & $14 \%$ groundnut & I $\%$ cholesterol \\
\hline 3 & $\mathbf{G}$ & $18.4 \%$ casein & Starch & $\begin{array}{l}15 \% \text { groundnut, } \\
1.5 \% \text { maize }\end{array}$ & $3.6 \%$ L-glutamine \\
\hline 4,5 & $\mathrm{H}$ & $22.8 \%$ gluten & Starch & $15 \%$ groundnut & $0.7 \%$ L-lysine \\
\hline 4 & I & $21.9 \%$ defatted gluten & Starch & I $5.9 \%$ groundnut & $0.7 \%$ L-lysine \\
\hline 4 & $\mathrm{~J}$ & $21.9 \%$ defatted gluten & Starch & $\begin{array}{l}15 \% \text { groundnut, } \\
0.9 \% \text { gluten }\end{array}$ & $0.7 \%$ L-lysine \\
\hline 4 & $\mathbf{K}$ & $21 \cdot 9 \%$ defatted gluten & Starch & $\begin{array}{l}\text { I } 5 \% \text { groundnut, } \\
0.9 \% \text { acetone- } \\
\text { soluble gluten }\end{array}$ & $0.7 \%$ L-lysine \\
\hline 4 & $\mathrm{~L}$ & $2 \mathrm{I} \cdot 9 \%$ defatted gluten & Starch & $\begin{array}{l}15 \% \text { groundnut, } \\
0.9 \% \text { acetone- } \\
\text { insoluble gluten }\end{array}$ & $0.7 \%$ L-lysine \\
\hline 5 & M & $22 \%$ casein & Starch & $\begin{array}{l}\mathrm{I} 4 \% \text { groundnut } \\
\mathrm{I} .5 \% \text { maize }\end{array}$ & I \% cholesterol \\
\hline 5 & $\mathbf{N}$ & $22.8 \%$ gluten & Starch & I $4 \%$ groundnut & $\begin{array}{c}\text { I \% cholesterol, } \\
0.7 \% \text { L-lysine }\end{array}$ \\
\hline 5 & $\mathrm{O}$ & $2 \mathrm{r} \cdot 3 \%$ defatted gluten & Starch & $\begin{array}{l}\text { I } 4 \% \text { groundnut, } \\
\text { I. } 5 \% \text { maize }\end{array}$ & $\begin{array}{l}\text { I \% cholesterol, } \\
0.7 \% \text { L-lysine }\end{array}$ \\
\hline 5 & $\mathbf{P}$ & $2 \times \cdot 3 \%$ defatted gluten & Starch & $\begin{array}{l}\mathrm{I}_{4} \% \text { groundnut, } \\
\mathrm{I} \cdot 5 \% \text { gluten }\end{array}$ & $\begin{array}{l}\text { I \% cholesterol, } \\
0.7 \% \text { L-lysine }\end{array}$ \\
\hline 5 & Q & $21 \cdot 7 \%$ casein & Starch & $\begin{array}{l}\text { I } 4 \% \text { groundnut, } \\
\text { I.5\% maize }\end{array}$ & $\begin{array}{l}\text { I \% cholesterol, } \\
0.3 \% \text { L-methionine }\end{array}$ \\
\hline 5 & $\mathbf{R}$ & $22 \%$ casein & Starch & $\begin{array}{l}\text { I } 4 \% \text { groundnut, } \\
1.5 \% \text { maize }\end{array}$ & r \% cholesterol \\
\hline
\end{tabular}

\section{Cholesterol determination}

Serum $(0.2 \mathrm{ml})$ was added to $5.0 \mathrm{ml}$ ethanol in a test-tube. A matched series of samples was treated in this way, after which the tubes were stoppered and shaken for $30 \mathrm{~min}$ at room temperature. They were then centrifuged at $1000 \mathrm{~g}$ for $5 \mathrm{~min}$ and duplicate $\mathrm{I} \cdot 0 \mathrm{ml}$ portions of the supernatant layer were taken for cholesterol determination by the method of Bowman \& Wolf (1962). 


\section{Phospholipid determination}

Duplicate $\mathrm{r} \cdot \mathrm{ml}$ portions of the same supernatant fraction as was used for the determination of cholesterol were transferred to test-tubes and dried, after which $0.5 \mathrm{ml}$ ro N- $\mathrm{H}_{2} \mathrm{SO}_{4}$ was added to each tube; the tubes were then heated until white fumes of $\mathrm{SO}_{3}$ began to appear. The tubes were allowed to cool for $30 \mathrm{~s}$ and two drops of $30 \%$ hydrogen peroxide (AR) were added to each of the tubes, which were then heated for a further $\mathrm{I}^{\cdot} 5 \mathrm{~min}$ to oxidize the carbon. The tubes were allowed to cool to room temperature, $4.4 \mathrm{ml}$ of double-distilled water were added, and the orthophosphate was determined by the method of Bartlett (1959).

\section{Triglyceride determination}

Serum $(0.3 \mathrm{ml})$ was added to $6.0 \mathrm{ml}$ chloroform-methanol (2:I) in a glass-stoppered test-tube. The series of tubes was shaken for $30 \mathrm{~min}, \mathrm{r} \cdot 2 \mathrm{ml}$ distilled water were added to each tube and the tubes were shaken for a further $5 \mathrm{~min}$. The tubes were cooled to about $4^{\circ}$ and centrifuged at $1000 \mathrm{~g}$ for $15 \mathrm{~min}$ to separate the phases. The upper, aqueous phase was removed and about $3 \mathrm{ml}$ of the chloroform layer were collected by means of a constriction pipette which could be slid past the disc of precipitated protein when the tube was tilted. Phospholipids were removed from the chloroform solution by adsorption on $300 \mathrm{mg}$ activated Doucil (Harrington Bros, London). Adsorption was facilitated by shaking the tubes for $30 \mathrm{~min}$ at room temperature. After centrifuging at $1000 \mathrm{~g}$ for $5 \mathrm{~min}$, $\mathrm{I} \mathrm{ml}$ portions of the supernatant fraction containing triglycerides were then taken and dried. Thin-layer chromatography of the supernantant layer showed it to be uncontaminated with phospholipids. Neutral glyceride hydrolysis, glycerol oxidation and the final formaldehyde assay were then performed as described by Carlson \& Wadström (1959).

\section{Statistical tests}

The experiments were designed as randomized blocks of, usually, genetic littermates (sometimes non-familial litter-mates supplied by Carworth Europe, Huntingdon). Tests for significance of the between-diet differences were made by Duncan's (1955) multiple $F$ test. When it was of interest to group certain diets within an experiment, as, for example, when a direct comparison of all diets containing sucrose and starch was required, an ordinary analysis of variance ( $F$ test) was used. Any missing values (due to unexpected death of the animal or insufficient serum for reliable replicate analyses) were calculated to obtain a better estimate of error and then discarded.

\section{RESULTS}

\section{Live-weight gains}

In Expt I (Table 2) the adult rats fed on sucrose gained more weight than those fed on starch. This was due to the slightly greater food consumption of the sucrosefed rats. On the other hand, comparison of the values obtained with the same carbohydrate, but with different proteins, did not reveal any significant difference. 


\section{Effects of proteins on serum lipids}

The outcome of comparisons of the different proteins depended very much on the ages of the animals used, since weanling rats were much more sensitive to protein differences than were adults. Much of the difference between the effects of casein and gluten was undoubtedly due to the lysine deficiency of the latter. However, the addition of sufficient lysine to bring about equalization in the weight gains (Expt 5) did not remove all the differences in the triglyceride analyses.

Table 3 (a). Expt 2. Growth rates, food intake:body-weight ratios and serum lipid concentrations in weanling male Wistar $(A s h)$ rats (ten genetic litters of six male rats/litter) maintained on various diets for $28 d$

(Compositions of the diets are given in Table $\mathrm{I}$ )

$\begin{array}{lccccc}\text { Diet } & \begin{array}{c}\text { Live-wt } \\ \text { gain }(\mathrm{g} / \mathrm{d})\end{array} & \begin{array}{c}\text { Ratio, food } \\ \text { intake (g): } \\ \text { live wt (g) }\end{array} & \begin{array}{c}\text { Cholesterol } \\ \text { (mg/roo ml) }\end{array} & \begin{array}{c}\text { Phospholipids Triglycerides } \\ (\mathrm{mg} / \mathrm{ro0} \mathrm{ml})\end{array} \\ \text { (mg/roo ml) }\end{array}$

Levels of significance by Duncan's $F$ test

(Values differ significantly $(P<0.01)$ except when they share a common underlining)

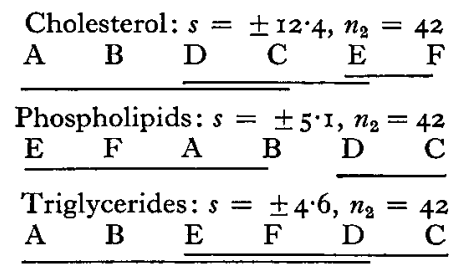

Table $3(b)$. Expt 2. Rearrangement of the results to facilitate comparisons of the effects of certain diet groups on serum lipids

\begin{tabular}{|c|c|c|c|}
\hline Diet group & $\begin{array}{l}\text { Cholesterol } \\
(\mathrm{mg} / \text { I0o } \mathrm{ml})\end{array}$ & $\begin{array}{l}\text { Phospholipids } \\
\text { (mg/roo ml) }\end{array}$ & $\begin{array}{l}\text { Triglycerides } \\
(\mathrm{mg} / \mathrm{I} 00 \mathrm{ml})\end{array}$ \\
\hline Starch $(A+C+E)$ & 94 & 88 & 23 \\
\hline Sucrose $(B+D+F)$ & 105 & 88 & 22 \\
\hline Casein $(A+B)$ & 66 & 78 & 15 \\
\hline Gluten $(C+D)$ & 89 & 114 & 32 \\
\hline Gluten + cholesterol $(E+F)$ & 140 & 74 & $2 \mathrm{I}$ \\
\hline \multicolumn{4}{|l|}{ Result of $F$ test } \\
\hline Starch $v$. sucrose & $P>0.20$ & $\ldots$ & - \\
\hline Casein $v$. gluten & $P<0.00 \mathrm{I}$ & $P<0.001$ & $P<0.001$ \\
\hline $\begin{array}{l}\text { Gluten } v \text {. gluten }+ \\
\text { cholesterol }\end{array}$ & $P<0.01$ & $P<0.001$ & $P<0.00 \mathrm{I}$ \\
\hline
\end{tabular}

In Expt 2, comparison of casein-fed animals with those fed on the gluten diet without added lysine reveals that, with gluten in the diet, the concentrations of all three lipid components in the serum were higher (Table $3 b$ ). In Expt I, such differences in lipid concentrations as did exist were less pronounced and were not statistically significant. 
The differences found in the weanling rats could be due to $(a)$ the lipid present in gluten but absent from casein, $(b)$ the lysine deficiency of gluten, or $(c)$ the high proportion of glutamine in gluten. The possible effects of glutamine on cholesterol and phospholipids were examined in Expt 3 (Table 4). As expected, both cholesterol and phospholipid concentrations were higher $(P<0.05)$ in the gluten-fed rats than in the casein-fed group. The position of the group given casein plus L-glutamine was

Table 4. Expt 3. Growth rates, food intake: body-weight ratios and serum lipid concentrations in weanling male Wistar (Ash) rats (eight genetic litters of three male rats/litter) maintained on various diets for $25 d$

(Compositions of the diets are given in Table I)

\begin{tabular}{|c|c|c|c|c|}
\hline Diet & $\begin{array}{l}\text { Live-wt } \\
\text { gain }(g / d)\end{array}$ & $\begin{array}{l}\text { Ratio, food } \\
\text { intake }(\mathrm{g}) \text { : } \\
\text { live wt }(\mathrm{g})\end{array}$ & $\begin{array}{l}\text { Cholesterol } \\
(\mathrm{mg} / \text { roo } \mathrm{ml})\end{array}$ & $\begin{array}{l}\text { Phospholipids } \\
\text { (mg/10o ml) }\end{array}$ \\
\hline $\mathrm{G}$ (casein + maize oil + glutamine) & $6 \cdot 32$ & $2 \cdot 17$ & $67 \cdot 9$ & $121 \cdot 0$ \\
\hline A (casein + maize oil) & 6.76 & $2 \cdot 17$ & $58 \cdot 7$ & $106 \cdot 0$ \\
\hline $\mathrm{C}$ (gluten) & $2 \cdot 05$ & $4 \cdot 99$ & $79 \cdot 7$ & $143^{\circ} 0$ \\
\hline
\end{tabular}

Levels of significance by Duncan's $F$ test

(Values differ significantly $(P<0.01)$ except when they share a common underlining)

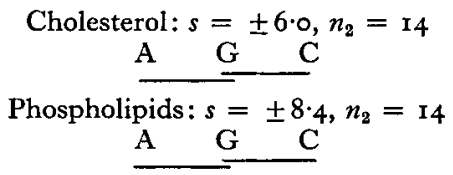

Table 5. Expt 4. Growth rates, food intake: body-weight ratios and serum lipid concentralions in weanling male Carworth rats (eight genetic litters of five male rats/litter) maintained on various diets for $2 \mathrm{I} d$

(Compositions of the diets are given in Table $\mathrm{I}$ )

\begin{tabular}{|c|c|c|c|c|c|}
\hline Diet & $\begin{array}{l}\text { Live-wt } \\
\text { gain }(g / d)\end{array}$ & $\begin{array}{l}\text { Ratio, food } \\
\text { intake }(\mathrm{g}) \text { : } \\
\text { live wt }(\mathrm{g})\end{array}$ & $\begin{array}{l}\text { Cholesterol } \\
(\mathrm{mg} / 100 \mathrm{ml})\end{array}$ & $\begin{array}{l}\text { Phospholipids } \\
\text { (mg//00 ml) }\end{array}$ & $\begin{array}{l}\text { Triglycerides } \\
(\mathrm{mg} / \mathrm{I} 00 \mathrm{ml})\end{array}$ \\
\hline H (gluten) & $5 \cdot 22$ & $2 \cdot 22$ & $8 I \cdot 0$ & $132 \cdot 8$ & $37 \cdot 8$ \\
\hline $\begin{array}{l}\text { I (defatted gluten } \\
+ \text { groundnut oil) }\end{array}$ & $4 \cdot 96$ & $2 \cdot 28$ & $76 \cdot 5$ & $121 \cdot 9$ & $3 I \cdot 7$ \\
\hline $\begin{array}{l}\text { J (defatted gluten } \\
+ \text { gluten oil) }\end{array}$ & $5 \cdot 04$ & $2 \cdot 22$ & $78 \cdot 0$ & $127 \cdot 4$ & $33 \cdot I$ \\
\hline $\begin{array}{l}\text { K (defatted gluten } \\
\text { + acetone-soluble } \\
\text { gluten oil) }\end{array}$ & 5.01 & $2 \cdot 21$ & $77 \cdot 5$ & $123 \cdot 0$ & $32 \cdot 9$ \\
\hline $\begin{array}{l}\text { L (defatted gluten } \\
\text { + acetone-insoluble } \\
\text { gluten oil) }\end{array}$ & 5.23 & $2 \cdot 24$ & $76 \cdot 4$ & $124: 3$ & $32 \cdot 8$ \\
\hline
\end{tabular}

Levels of significance by Duncan's $F$ test

(Values differ significantly $(P<0 \cdot 05)$ except when they share a common underlining)

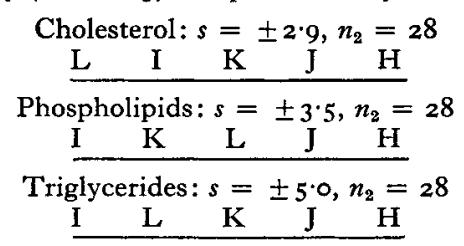


intermediate and values for it were not significantly different from those for either of the other groups. Therefore, although L-glutamine may contribute to the 'gluten effect', this amino acid is not solely responsible.

The effects of addition of lysine to gluten diets were seen in Expt 5. The cholesterol concentrations were not affected, whereas there was a diminution of both phospholipids and triglycerides (see Table 6, diet $\mathrm{N}$ ). This reduction in phospholipid concentration rendered diet $\mathrm{H}$ indistinguishable from almost all the remaining diets. However, the triglyceride concentration was not so markedly reduced and a similar effect was obtained with cholesterol in the diet. Only when lysine and cholesterol were added together in the gluten diet $\mathrm{N}$ were the concentrations of triglycerides reduced to the concentrations found in the casein diets.

The $0.3 \%$ supplement of L-methionine in casein diet Q seemed to have no significant effect on the concentration of any of the serum lipids.

Table 6. Expt 5. Growth rates, food intake: body-weight ratios and serum lipid concentrations in weanling male Carworth rats (eight standardized litters of ten male rats/litter) maintained on various diets for $14 d$

(Compositions of the diets are given in Table $\mathrm{I}$ )

\begin{tabular}{|c|c|c|c|c|c|}
\hline Diet & $\begin{array}{l}\text { Live-wt } \\
\text { gain }(\mathrm{g} / \mathrm{d})\end{array}$ & $\begin{array}{l}\text { Ratio, food } \\
\text { intake }(\mathrm{g}) \text { : } \\
\text { live wt }(\mathrm{g})\end{array}$ & $\begin{array}{l}\text { Cholesterol } \\
(\mathrm{mg} / \mathrm{r} 00 \mathrm{ml})\end{array}$ & $\begin{array}{l}\text { Phospholipids } \\
\text { (mg/roo ml) }\end{array}$ & $\begin{array}{l}\text { Triglycerides } \\
\text { (mg/100 ml) }\end{array}$ \\
\hline $\begin{array}{l}\text { A (casein + maize oil) } \\
\text { M (casein + maize oil } \\
\text { + cholesterol) }\end{array}$ & $\begin{array}{l}5 \cdot 62 \\
5 \cdot 76\end{array}$ & $\begin{array}{l}\mathrm{I} \cdot 85 \\
\mathrm{r} \cdot 83\end{array}$ & $\begin{array}{l}71 \cdot 6 \\
77 \cdot 3\end{array}$ & $\begin{array}{r}105 \cdot 4 \\
83 \cdot 2\end{array}$ & $\begin{array}{l}20.9 \\
\mathrm{r} 8.6\end{array}$ \\
\hline $\mathrm{C}$ (gluten) & $I \cdot 39$ & $5 \cdot 30$ & 90.7 & $146 \cdot 1$ & $47 \cdot 3$ \\
\hline $\begin{array}{l}\text { H (gluten + I-lysine } \\
\text { hydrochloride) }\end{array}$ & $5 \cdot 96$ & $r \cdot 84$ & $8 \mathrm{r} \cdot 0$ & $109 \cdot 7$ & $37 \cdot 8$ \\
\hline $\mathrm{E}$ (gluten + cholesterol) & $\mathrm{I} \cdot 53$ & $5 \cdot 62$ & $90 \cdot 2$ & I $19 \cdot 3$ & 33.5 \\
\hline $\begin{array}{l}N \text { (gluten + choles- } \\
\text { terol + L-lysine } \\
\text { hydrochloride) }\end{array}$ & $5 \cdot 37$ & 2.02 & $85 \cdot 3$ & $96 \cdot 3$ & $21 \cdot 3$ \\
\hline $\begin{array}{l}\text { O (defatted gluten + } \\
\text { cholesterol + maize } \\
\text { oil + L-lysine hydro- } \\
\text { chloride) }\end{array}$ & $5 \cdot 40$ & $2 \cdot 01$ & $78 \cdot 4$ & $89 \cdot 7$ & I8.2 \\
\hline $\begin{array}{l}\text { P (defatted gluten }+ \\
\text { cholesterol + gluten } \\
\text { oil + L-lysine hydro- } \\
\text { chloride) }\end{array}$ & 5.91 & I'79 & $92 \cdot 3$ & $99 \cdot 2$ & $19 \cdot 6$ \\
\hline $\begin{array}{l}Q \text { (casein + choles- } \\
\text { terol + maize oil + } \\
\text { L-methionine) }\end{array}$ & 6.03 & $I \cdot 7 r$ & $80 \cdot 7$ & $98 \cdot 5$ & $23 \cdot 7$ \\
\hline $\begin{array}{l}\mathrm{R} \text { (casein + choles- } \\
\text { terol + gluten oil) }\end{array}$ & $5 \cdot 80$ & $I \cdot 75$ & $74 \cdot 5$ & $81 \cdot 4$ & $21 \cdot 0$ \\
\hline
\end{tabular}

Levels of significance by Duncan's $F$ test (Values differ significantly $(P<0.01)$ except when they share a common underlining)

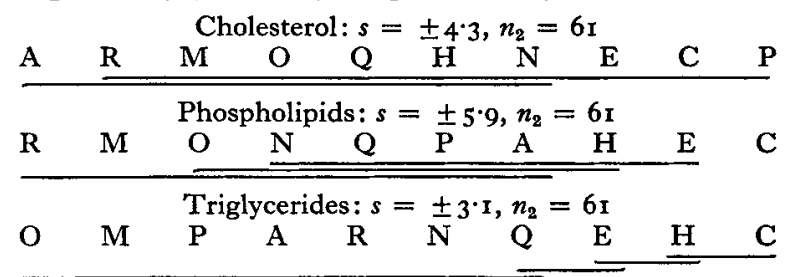




\section{Effects of dietary lipids on serum lipids}

In Expt 4 (Table 5) an attempt was made to examine the role of gluten oil. No significant differences in response to these diets were found in the triglyceride, phospholipid or cholesterol concentrations, despite the tendency for the lipid concentrations to be higher in the rats fed on the diet with gluten. In this experiment the diets contained no supplementary lysine or cholesterol, but in Expt 5 (Table 6) both these substances were present (diets N, O and P). Again, there was no effect on the triglycerides, whereas the absence of gluten oil in diet $\mathrm{O}$ tended to lower the serum phospholipid level. There was, however, a difference in the cholesterol concentrations when Expt 5 is compared with Expt 4, since the gluten $\operatorname{diet} \mathrm{N}$ and defatted gluten plus gluten oil diet $\mathrm{P}$ gave higher serum cholesterol concentrations than the defatted gluten plus maize oil diet $\mathrm{O}$, and this difference reached the $5 \%$ level of significance, but not the probably more valid $\mathrm{I} \%$ level. The addition of gluten oil to casein, in the presence of cholesterol, did not affect the lipid concentrations (cf. the results with diets $M$ and $R$, Table 6 ).

Dietary cholesterol in the weanling, gluten-fed rats resulted in decreased serum triglycerides and phospholipids (Expts 2 and 5 ). These differences were significant in both experiments. Unfortunately, the serum cholesterol response is not clear since there was a very definite increase in concentration in Expt 2 with Wistar (Ash) rats (Table $3 b$ ), but there was no change in the serum cholesterol values in Expt 5 in Carworth rats. This finding resembles that observed in an earlier experiment in which Carworth rats were used and may be due to a real strain difference.

\section{DISCUSSION}

The results reported here support the impression gained in earlier trials that differences in the metabolism of starch and sucrose in the rat do not influence the serum lipid concentrations under the prevailing experimental conditions. This conclusion confirms the findings of Carroll (1963), who found only slight variations, or none at all, in the serum cholesterol concentrations of weanling Sprague-Dawley rats fed for $14^{-19} \mathrm{~d}$ on diets containing $60 \%$ of either rice starch or sucrose. The presence of different dietary lipids did not affect the results. On the other hand, Allen \& Leahy ( 1966 ) found that adult Medical Research Council Wistar-derived rats fed for 20 weeks on diets containing $80 \%$ sucrose had significantly higher serum cholesterol concentrations than rats fed on liquid glucose (partly hydrolysed starch), but there were no differences in response among groups given dextrose, fructose or sucrose. Responses to diets containing $39 \%$ of either starch or sucrose in BHE and Wistar strains were compared at $\mathrm{I} 50$ and $350 \mathrm{~d}$ by Taylor, Conway, Schuster \& Adams ( $\mathrm{I} 967$ ). It was found that there were marked strain differences and that concentrations of serum cholesterol and total fatty acids increased with age, irrespective of the type of carbohydrate, particularly in the BHE strain. In this strain both of the measured components were greater in the sucrose-fed rats at both 150 and $35^{\circ} \mathrm{d}$. But in the Wistar strain the differences seen at $150 \mathrm{~d}$ had disappeared by $35^{\circ} \mathrm{d}$. Fillios, Naito, 
Andrus, Portman \& Martin (1958) studied the effects of sucrose and starch on a SpragueDawley strain of mature male and female rats given what were basically atherogenic diets deficient in essential fatty acids. Sucrose resulted in higher serum cholesterol concentrations than starch after 3 weeks on the experimental diets, but the difference became statistically non-significant after 6 weeks and disappeared completely after I2 weeks.

Though the effects of dietary carbohydrates on the serum phospholipid and triglyceride concentrations of rats have been much less extensively studied, it is evident that the observed response in serum cholesterol depends greatly upon the strain of animal used and the time which individuals spend on the test diets.

Nath, Harper \& Elvehjem (1959) compared the effects of several dietary proteins in the presence of sucrose and hydrogenated coconut oil; in several of the experiments cholesterol and cholic acid were included. Simple comparison of their experiments with my own is not possible since, in their experiments, the rats were almost certainly deficient in essential fatty acids whereas this was not so in the tests reported here. Nath and his co-workers used hydrogenated coconut oil rather than a natural oil in a deliberate attempt to reproduce, in rats, the serum cholesterol concentrations found in certain human pathological conditions. In a later series of experiments, Nath, Seidel \& Harper (196I) showed that much of the gluten effect, a lowering of serum cholesterol in their trials, was attributable to the essential fatty acid content of gluten and that gluten oil could largely be replaced by commercially available maize oil. They also thought that polyunsaturated fatty acids were important in reversing the diet-induced hypercholesterolaemia. It also appeared from their experiments that there was some synergism between unsaturated fatty acids and methionine, at least when casein formed only 10\% of the diet (Seidel, Nath \& Harper, r960; Nath et al. I96I). The action of supplementary methionine seemed to disappear at higher protein levels, since this amino acid neither raised nor lowered serum triglyceride, phospholipid or cholesterol concentrations when added to $22 \%$ casein in my Expt 5 .

Perhaps the greatest discrepancy between the results of Nath et al. (1959) and my own lies in the observed effects of cholesterol in the diets. They found that the addition of cholesterol increased the serum cholesterol more in casein-fed than in gluten-fed rats. In my Expt 5, however, I \% dietary cholesterol had no effect on the measured lipids of casein-fed rats and, in the groups given gluten and gluten plus L-lysine, dietary cholesterol did not affect serum cholesterol, although both triglyceride and phospholipid concentrations were reduced by addition of cholesterol. The difference between these findings is possibly due to the strains of rat used. Serum cholesterol is derived from two sources, diet and liver synthesis. There is some feedback control of liver synthesis which helps to stabilize the serum concentration (Carroll, I967), and whether or not serum cholesterol concentrations alter in response to dietary supplementation depends on the efficiency of the feed-back mechanism. Its efficiency certainly varies between species and may well vary between strains.

Significant differences in response were not found between rats given untreated or defatted gluten, except possibly in the serum cholesterol concentrations when lysine and cholesterol were included in the diets. Therefore, the attempt to remove, 
with lipid solvents, the factor(s) in gluten responsible for the apparently specific effects of this protein were unsuccessful. Nath $e$ t al. (1959, 1961) had more success since they isolated a factor which was definitely associated with the lipid fraction and was still active when added back to the defatted gluten. Yet another result was obtained by de Groot (1959), who found that butanol-extracted wheat gluten was nearly as active as untreated wheat gluten in lowering serum cholesterol concentration (on an atherogenic diet).

In conclusion, it seems that, when there is a deficiency of essential fatty acids and inadequate proportions of good-quality protein, the oil in gluten reduces the hypercholesterolaemia induced by dietary cholesterol. An inadequate supply of good protein can be brought about by giving a rather low proportion of casein (as in the experiments of Nath and his co-workers) or by giving higher proportions of a poor protein such as gluten. It is believed by other workers that the active factor in protein is the methionine content (Fillios \& Mann, 1954; Seidel et al. 1960). In my experiments, with diets with a much higher level of casein $(22 \%)$, the addition of $0.3 \%$ methionine had no observable effect upon the concentrations of any of the three lipids measured. When there is no deficiency of essential fatty acids gluten appears to have the opposite effect and in fact raises the concentration, not only of serum cholesterol, but also of serum triglycerides and phospholipids. This effect disappears in adult rats and is smaller in weanling rats whose diet is supplemented with L-lysine. Nevertheless, some excess of serum triglyceride remains in the weanling rats fed on the diet with $22.8 \%$ gluten plus $0.7 \%$ L-lysine hydrochloride over those litter-mates fed on the unsupplemented $22 \%$ casein diet. The reason for this has not been determined.

Atherogenic diets have been used frequently in experiments involving rats when some parallel with human atheroma is sought. These diets certainly raised the serum cholesterol concentrations of the animals to values at least as high as those found in man, but it has often escaped notice that, in doing so, they have caused these animals to become quite severely deficient in essential fatty acids, whereas man is very resistant to this condition. Hence, the physiological differences between rat and man may be too large in this respect to justify extending conclusions reached with rats to human atheromatous conditions.

Without the advice of the late Dr J. Pace and Dr B. Hutchinson and the technical assistance of Mrs Jill Osborne, this work could not have been accomplished. To these people in particular I am indebted, but I should like also to extend my thanks to $\mathrm{Mr}$ Seed, who cared for the animals.

\section{REFERENCES}

Allen, R. J. L. \& Leahy, J. S. (I966). Br. F. Nutr. 20, 339.

Bartlett, G. R. (1959). F. biol. Chem. 234, 466.

Bowman, R. E. \& Wolf, R. C. (1962). Clin. Chem. 8, 296.

Carlson, L. A. \& Wadström, L. B. (1959). Clinica chim. Acta 4, 197.

Carroll, C. (1963). F. Nutr. 79, 93.

Carroll, K. K. (1967). F. Am. Oil Chem. Soc. 44, 607.

de Groot, A. P. (I 959). Nature, Lond. 184, 903.

Duncan, D. B. (1955). Biometrics Ir, r. 
Fillios, L. C. \& Mann, G. V. (1954). Metabolism 3, 16.

Fillios, L. C., Naito, C., Andrus, S. B., Portman, O. W. \& Martin, R. S. (1958). Am. F. Physiol. I94, 275.

Jones, J. H. \& Foster, C. (1942). F. Nutr. 24, 245.

Nath, N., Harper, A. E. \& Elvehjem, C. A. (1959). Can. F. Biochem. Physiol. 37, 1375.

Nath, N., Seidel, J. C. \& Harper, A. E. (196r). F. Nutr. 74, 389.

Seidel, J. C., Nath, N. \& Harper, A. E. (Ig6o). F. Lipid Res. 1, 474.

'Taylor, D. D., Conway, E. S., Schuster, E. M. \& Adams, M. (1967). F. Nutr. 9r, 275. 